ISSN : 2302 - 7517, Vol. 03, No. 01

\title{
PENGARUH KEKUASAAN TERHADAP PERILAKU UNJUK RASA MASYARAKAT DI SEKITAR INDUSTRI EKSTRAKTIF MINYAK BUMI
}

\author{
Power Influence Towards Society Protest Behavior Around The Extractive Petroleum Industry \\ Nyimas Nadya Izana*), Nurmala Katrina Pandjaitan, dan Satyawan Sunito \\ Departemen Sains Komunikasi dan Pengembangan Masyarakat, Fakultas Ekologi Manusia, IPB \\ *Email: nyimasnadyaizana@gmail.com
}

\begin{abstract}
One of the extractive petroleum industries that are currently present in Indonesia is the PCI Industry which cooperates with Pertamina. PCI Industry is located in Bojonegoro, East Java and established in 2002. Ever since the presence of the extractive petroleum industry, conflict with society is started to begin. The method used in this study was a quantitative method that was supported by quantitative data. Qualitative data were obtained by observations and in-depth interviews. Quantitatif data using questionnaires were obtained from two villages with 100 respondents. Respondents were divided into two geoups: responden who did non participate in the protest and respondents who participated in the protest. This study aims to analyze the root problem of public protest occurence towards the PCI Industry, analyze the presence of PCI Industry that raises a certain protest behavior of society and analyze the effect of local leaders power on the dynamics and behavior of the society protest. The result showed that the root problem of public protes occurence towards the PCI Industry is an opportunities to work in the PCI Industry, CSR funds, environmental demanding. The protest behavior of local people due to the presence of the PCI Industry is in accordance with the theory of planned behavior which mentions that attitude is not enough to determine behavior, but there are subjective norms and perceived behavioral control. The effect of local leader power on the dynamics and behavior of the society protest is appreciable.
\end{abstract}

Keywords: attitudes, behavior control, power, subjective norms, work and business opportunities

\begin{abstract}
ABSTRAK
Salah satu industri minyak bumi ekstraktif yang saat ini hadir di Indonesia adalah industri PCI yang bekerja sama dengan Pertamina. PCI Industri terletak di Bojonegoro, Jawa Timur dan didirikan pada tahun 2002. Sejak kehadiran industri perminyakan ekstraktif, konflik dengan masyarakat lokal mulai terjadi. Metode yang digunakan dalam penelitian ini adalah metode kualitatif yang didukung oleh data kuantitatif. Data kualitatif diperoleh dengan observasi dan wawancara mendalam. Data kuantitatif menggunakan kuesioner diperoleh dari dua desa dengan 100 responden. Responden dibagi menjadi dua kelompok: responden yang tidak ikut berpartisipasi dalam protes dan responden yang berpartisipasi dalam protes. Penelitian ini bertujuan untuk menganalisis akar masalah timbulnya unjuk rasa masyarakat terhadap Industri PCI, menganalisis keberadaan Industri PCI terhadap sikap warga desa yang ada di sekitar Industri PCI, dan menganalisis pengaruh kekuasaan pemimpin lokal terhadap dinamika dan perilaku unjuk rasa warga desa. Hasil penelitian menunjukkan bahwa akar masalah timbulnya unjuk rasa terhadap Industri PCI adalah peluang bekerja, dana CSR dan ganti rugi perusahaan sebagai kompensasi kerusakan lingkungan yang terjadi. Perilaku protes dari masyarakat setempat karena kehadiran industri PCI sesuai dengan teori perilaku terencana yang menyebutkan sikap itu tidak cukup untuk menentukan perilaku, tetapi ada norma subjektif dan kontrol perilaku yang dirasakan. Pengaruh kekuasaan pemimpin lokal pada dinamika dan perilaku protes masyarakat cukup besar.
\end{abstract}

Kata kunci: kekuatan, kontrol perilaku, norma subjektif, pekerjaan dan peluang bisnis, sikap

\section{PENDAHULUAN}

\section{Latar Belakang}

Pembangunan ekonomi suatu bangsa merupakan pilar penting bagi terselenggaranya proses pembangunan. Salah satu sektor yang berperan penting pada proses pembangunan adalah sektor industri, untuk mendukung sektor ini maka penting untuk penanaman modal asing. Salah satu sektor industri yang membutuhkan modal 
asing yaitu industri ekstraktif minyak dan gas bumi (migas) karena eksplorasi migas bergantung pada modal dan teknologi yang terus meningkat, sehingga ekstraksi migas membutuhkan kerjasama antara pemerintah negara bersangkutan dengan aktor-aktor swasta internasional yang sudah berpengalaman (Humphreys et al, 2007).

Negara Indonesia dalam mengelola sumber daya migas butuh melakukan kerjasama dengan perusahaan-perusahaan asing maupun nasional untuk mengekstrasi aset yang dimilikinya. Hal ini dikarenakan dalam mengekstraksi aset tersebut membutuhkan investasi yang sangat besar, teknologi yang canggih serta tenaga ahli yang mutunya tinggi karena menyangkut resiko yang sangat tinggi (Sanusi, 2004). Di samping itu sumber daya alam ini merupakan sumber daya yang strategis dan sekaligus primadona pendukung pertumbuhan ekonomi di Indonesia (Sumardjono et al, 2011) dan juga menjadi penggerak utama pembangunan di Indonesia sehingga sering digunakan sebagai sumber dasar dalam perencanaan Anggran Pendapatan dan Belanja Negara (APBN)

Ada beberapa masalah sosial yang terjadi ketika hadirnya industri ekstraktif minyak bumi di pedesaan antara lain menyebabkan keresahan dan resistensi sosial dikalangan penduduk lokal yang teralienasi dari proses pembangunan yang sedang berlangsung di wilayahnya, terjadinya pergeseran budaya pada kalangan generasi muda dengan hadirnya pendatang, peran tradisi hanya tinggal sebagai ritual saja bukan lagi sebagai penentu perilaku, memudarnya daya kohesi sosial sesama penduduk lokal serta menimbulkan kecemburuan sosial (Suyanto, 2008). Selain itu ternyata kehadiran industri juga memunculkan praktek-praktek enterpreneur seperti urusan administrasi pembebasan tanah, makelar tanah dan badan-badan usaha yang memfasilitasi kebutuhan industri (Huda, 2011). Sayangnya peluang usaha ini hanya diakses oleh aktor lokal yang mempunyai kekuasaan di dalam masyarakat seperti: pejabat kecamatan, perangkat desa, para elit desa dan preman setempat. Produksi sumber daya alam seringkali rawan terhadap perasaan frustasi terutama di wilayah tepat sumber alam itu diambil. Proses ekstraksi itu sendiri bisa menyebabkan perpindahan penduduk secara paksa, gelombang baru perpindahan penduduk, tekanan populasi dan polusi atau kerusakan lingkungan. Meskipun hanya terjadi perubahan minimal terhadap kondisi lokal, warga yang bertempat tinggal di wilayah yang kaya sumber daya alam akan merasa punya hak istimewa atas kekayaan sumber alam tersebut (Humphreys et al. 2007).

Hal ini membuat dilema tersediri bagi bangsa Indonesia dalam pengelolaan sumber daya minyak bumi. Di satu sisi sumber daya minyak bumi sangat penting dalam pembangunan ekonomi negara. Di sisi lain memberikan dampak tersendiri pada masyarakat lokal dan lingkungan seperti yang telah diungkapkan di atas. Khususnya mengenai industri ekstraktif (eksploitasi sumber daya alam) nampaknya interaksi antara komunitas lokal dan perusahaan cenderung bermasalah. Prayogo (2008) mengungkapkan bahwa resistensi komunitas lokal pada perusahaan cenderung tinggi sehingga rentan terjadi konflik. Sumber utama konflik cenderung berkaitan dengan sumber ekonomi yaitu dieksploitasi sumber daya alam lokal yang tidak tergantikan dari wilayah tersebut.

Salah satu industri ekstraktif minyak bumi yang saat ini hadir di Indonesia yaitu Industri PCI yang bekerja sama dengan Pertamina. Lokasi industri tersebut berada di Kabupaten Bojonegoro, Jawa Timur sejak tahun 2002. Industri ekstraktif minyak bumi ini memperoleh izin konsesi di dua desa yang telah menghasilkan 12 sumur minyak mentah. Semenjak adanya industri ekstraktif minyak bumi belakangan ini mulai sering terjadi konflik dengan masyarakat setempat diantaranya unjuk rasa menuntut peluang bekerja di dalam perusahaan, juga agar dibuat tali asih (semacam dana CSR) pada saat dilakukannya proses side track. Selain itu masyarakat ingin program community development $(\mathrm{CD})$ diganti dengan program-program yang dapat menunjang program- program yang sudah ada di dalam masyarakat. Melihat tuntutan masyarakat tersebut maka timbul pertanyaan apakah beroperasinya Industri PCI selama ini membawa manfaat bagi warga desa, terutama dalam peluang bekerja dan peluang usaha? Apakah setiap warga desa dapat memanfaatkan peluang-peluang tersebut? atau hanya pihak-pihak tertentu yang dapat memanfaatkannya melalui kekuasaan yang ada?

\section{Rumusan Masalah}

Berdasarkan latar belakang dan penjelasan di atas, maka dirumuskan beberapa masalah yang menjadi pertanyaan dalam penelitian ini, yaitu:

1. Apa yang menjadi akar masalah timbulnya unjuk rasa warga desa terhadap Industri PCI?

2. Bagaimana keberadaan Industri PCI terhadap sikap warga desa yang ada di sekitar Industri PCI?

3. Bagaimana pengaruh kekuasaan pemimpin lokal terhadap dinamika dan perilaku unjuk rasa warga desa?

\section{Tujuan Penelitian}

Tujuan penelitian ini adalah untuk menganalisis pengaruh kekuasaan terhadap perilaku unjuk rasa masyarakat di sekitar industri ekstraktif minyak bumi dan tujuan penelitian secara lebih rinci dirumuskan sebagai berikut:

1. Menganalisis akar masalah timbulnya unjuk rasa masyarakat terhadap Industri PCI.

2. Menganalisis keberadaan Industri PCI terhadap sikap warga desa yang ada di sekitar Industri PCI.

3. Menganalisis pengaruh kekuasaan pemimpin lokal terhadap dinamika dan perilaku unjuk rasa warga desa.

\section{Kegunaan Penelitian}

Secara umum, hasil dari studi ini dapat memberikan pengetahuan sosiologi pedesaan. Melalui studi ini diharapkan dapat bermanfaat bagi pengambil kebijakan dalam merumuskan dan mengambil kebijakan terkait dengan industri ektraktif minyak bumi yang akan beroperasi di daerah padat penduduk. Selain itu, penelitian ini akan bermanfaat bagi masyarakat sebagai acuan untuk melakukan persiapan sosial jika wilayah mereka akan dijadikan sebagai lokasi perusahaan ekstraktif. Dengan itu, masyarakat tidak akan dirugikan secara ekologi, ekonomi, sosial dan budaya.

\section{TINJAUAN PUSTAKA}

\section{Sikap}

Ada beberapa pengertian sikap yang diungkapkan oleh 
para ahli, diantaranya Jones mengungkapkan sikap adalah perantara antara stimuli (contohnya perpaduan aktivitas yang menimbulkan perasaan atau tingkah laku) dan respon (mendukung/favorable atau tidak mendukung/ unfavorable). Katz (1960) dalam Jones mendefinisikan sikap sebagai "kecenderungan dari individu untuk mengevaluasi beberapa simbol atau objek atau aspek mengenai bagaimana dia memandang dunianya dari sisi baik atau buruk." Sikap merupakan ekspresi yang mencerminkan perasaan inner feeling), apakah seseorang senang atau tidak senang, suka atau tidak suka dan setuju atau tidak setuju terhadap suatu objek. Objek yang dimaksud bisa berupa merek, layanan, pengecer, perilaku tertentu dan lainlain (Schifman dan Kanuk (1997) dalam Siswanta et al. 2014).

Baron dan Byrne (2004) sikap adalah evaluasi terhadap berbagai aspek dalam dunia sosial, sedangkan Secord dan Backman (1964) dalam Azwar (1998) mendefinisikan sikap adalah sebagai keteraturan tertentu dalam hal perasaan (afeksi), pemikiran (kognisi) dan predisposisi tindakan (konasi) seseorang terhadap suatu aspek lingkungan sekitarnya. Dapat disimpulkan bahwa sikap adalah evaluasi baik atau kurang baik terhadap lingkungan sosial individu yang dipengaruhi oleh pikiran, perasaan kemudian dilakukan melalui tindakan.

Mengikuti skema triadik, struktur sikap terdiri atas tiga komponen yang saling menunjang (Azwar, 1998), yaitu komponen kognitif, komponen afektif dan komponen konatif.

1. Komponen kognitif, yaitu komponen ini menyangkut kepercayaan seseorang mengenai apa yang berlaku atau apa yang benar bagi objek sikap. Sekali kepercayaan itu telah terbentuk, maka kepercayaan itu akan menjadi dasar pengetahuan seseorang mengenai apa yang dapat diharapkan dari objek tertentu. Kepercayaanlah yang menyerderhanakan dan mengatur apa yang dilihat atau yang ditemui.

2. Kompoen afektif, yaitu komponen yang menyangkut masalah emosional subjektif seseorang terhadap suatu objek sikap. Secara umum, komponen ini disamakan dengan perasaan yang dimiliki terhadap sesuatu. Komponen afektif ini banyak dipengaruhi oleh kepercayaan atau apa yang dipercayai benar dan berlaku bagi objek yang dimaksud.

3. Komponen konatif, yaitu komponen ini menunjukkan bagaimana perilaku atau kecenderungan berperilaku yang ada dalam diri seseorang berkaitan dengan objek sikap yang dihadapi. Kaitan ini didasari oleh asumsi bahwa kepercayaan dan perasaan banyak mempengaruhi perilaku.

Ada berbagai faktor dalam mempengaruhi pembentukan sikap menurut Azwar (1998) adalah pengalaman pribadi, kebudayaan, orang lain yang dianggap penting, media massa, institusi atau lembaga pendidikan dan lembaga agama, serta faktor emosi dalam diri individu.

\section{Teori Hubungan Sikap dan Perilaku}

Terdapat dua teori yang menjelaskan mengenai sikap yang mempengaruhi tingkah laku, yaitu teori tindakan yang beralasan (theory of reasoned action) yang dikemukakan oleh Icek Ajzen dan Martin Fishbein dan teori tingkah laku berencana (theory of planned behavior)yang dikembangkan lebih lanjut oleh Ajzen dari teori yang pertama.Ajzen(1991) mengungkapkan bahwa teori perilaku yang direncakan ini ditemukan oleh bukti empiris di mana niat untuk melakukan perilaku dari berbagai jenis dapat diprediksikan dengan akurasi yang tinggi dari sikap terhadap perilaku, norma subjektif dan kontrol perilaku yang dipersepsikan.

Teori tindakan yang beralasan (theory of reasoned action) adalah sebuah teori yang menyatakan bahwa keputusan untuk melakukan tingkah laku tertentu adalah hasil dari sebuah proses rasional di mana pilihan tingkah laku dipertimbangkan, konsekuensi dan hasil dari setiap tingkah laku dievaluasi, dan dibuat sebuah keputusan apakah akan bertindak atau tidak. Kemudian keputusan ini direfleksikan dalam tujuan tingkah laku, yang sangat berpengaruh terhadap tingkah laku yang tampil (Ajzen (1987) dalam Baron dan Byrne, 2003). Pada teori ini, terdapat cara atau atribut yang menjelaskan teori ini ada dua faktor, yaitu sikap terhadap tingkah laku (apakah seseorang berpikir tindakan itu akan menimbulkan konsekuensi positif atau negatif) dan norma subjektif (persepsi seseorang apakah orang lain akan menyetujui atau menolak tingkah laku tersebut). Ajzen menganggap bahwa hubungan antara sikap dan perilaku dalam teori tindakan beralasan tidak menjelaskan mengenai perilaku yang tidak sepenuhnya dapat dikendalikan oleh orang, meski ia mempunyai sikap yang positif terhadap perilaku yang dimaksud (Fakultas Psikologi UI ,2012).

Hubungan sikap dengan perilaku dapat dijelaskan menggunakan teori perilaku berencana (Theory of Planned Behavior). Secara umum sikap terdiri atas tiga komponen yaitu kognitif, afektif dan konatif. Ajzen dan Fishben (2000) dalam Waysima (2011) mengungkapkan bahwa teori perilaku berencana adalah salah satu pendekatan relasi sikap dengan perilaku yang mengeluarkan komponen konatif dari peubah sikap karena komponen konatif dan kognitif sebagai konsep yang erat hubungannya dengan sikap namun bukan hal yang sama. Komponen afektif adalah komponen yang menyangkut masalah emosional subjektif seseorang terhadap suatu objek sikap, sedangkan kognitif adalah komponen yang menyangkut kepercayaan seseorang mengenai apa yang berlaku atau apa yang benar bagi objek sikap (Azwar, 1998). Menurut Ajzen (1991) dalam Waysima (2011) komponen konatif atau kecenderungan bertindak (behavioral intention) bersama dengan kontrol perilaku yang dipersepsikan (perceived behavioral control) merupakan bagian utama dari ragam perilaku yang dimaksud. Secara umum dikatakan bahwa semakin kuat kecederungan seseorang untuk melakukan unjuk rasa, semakin mudah terjadinya perilaku unjuk rasa.

Ajzen menambahkan satu lagi determinan perilaku yang disebut sebagai perceived behavior control (PBC) atau kontrol tingkah laku yang dipersepsikan. Kontrol tingkah laku yang dipersepsikan merupakan persepsi terhadap kesulitan sebuah perilaku untuk dan dilaksanakan. PBC merefleksikan pengalaman masa lalu dan antisipasi terhadap hambatan yang mungkin terjadi ketika melakukan sebuah perilaku (Fakultas Psikologi UI, 2012). Kontrol perilaku yang dipersepsikan merupakan kondisi pada saat orang percaya bahwa suatu tindakan itu mudah atau sulit dilakukan. Kontrol ini dapat diperoleh dari berbagai hal diantaranya pengalaman perilaku yang sama sebelumnya atau pengalaman yang diperoleh karena melihat orang lain melaksanakan itu sehingga ia memiliki keyakinan bahwa 
ia akandapat melaksanakannya, ketersediaan waktu untuk melaksanakan perilaku tersebut dengan adanya fasilitas untuk melaksanakannya danmemiliki kemampuan untuk mengatasi setiap kesulitan yang menghambat pelaksanaan perilaku (Aryani, 2010). Ajzen (1991) mengungkapkan bahwa faktor utama dalam teori perilaku berencana adalah niat individu untuk melakukan perilaku tententu. Sebelum mencapai seseorang mempunyai niat untuk ada keyakinan (beliefs) yang mempengaruhi pada sikap terhadap perilaku tertentu, norma subjektif dan kontrol perilaku yang dipersepsikan. Ketiga variabel independen akan mempengaruhi variabel dependen (niat) yang pada akhirnya akan menentukan apakah seseorang akan berperilaku akan dilakukan atau tidak. Dharmmesta (1998) mengungkapkan ada beberapa hal yang perilaku diperhatikan pada variabel niat adalah (1) Niat dianggap sebagai "penangkap" atau perantara faktorfaktor motivasional yang mempunyai dampak pada suatu perilaku, (2) niat menunjukkan seberapa keras seseorang berani mencoba, (3) niat juga menunjukkan seberapa banyak upaya yang direncanakan seseorang untuk dilakukan dan (4) niat adalah paling dekat berhubungan dengan perilaku selanjutnya. Pada Gambar 1 menunjukkan panah dari kontrol perilaku yang dipersepsikan langsung ke perilaku dimungkinkan terjadi, akan terjadi apabila ada kesepakatan antara persepsi tentang kontrol dan kontrol aktual orang tersebut atas perilakunya. Kontrol aktual adalah ketersediaan kesempatan dan sumber yang dimiliki (misalnya uang, waktu).

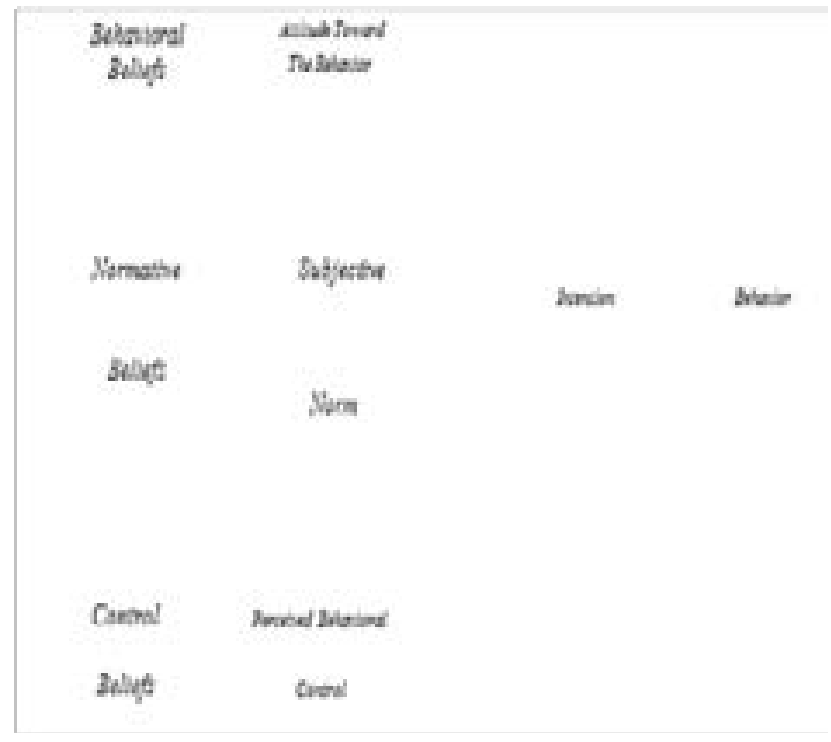

Gambar 1. Theory of Planned Behavior (Ajzen 1991)

Pada theory of planned behavior juga mengutamakan niat tetapi terdapat tambahan variabel yang mempengaruhi niat untuk seseorang berperilaku (lihat pada Gambar 1), yaitu:

1. Behavioral beliefs yaitu keyakinan dalam berperilaku mengarahkan pada konsekuensi tertentu dan evaluasi seseorang terhadap konsekuensi dari perilaku tersebut. Hasil dari keyakinan dan evaluasi akan membentuk variabel sikap. Sikap terhadap perilaku adalah sejauhmana evaluasi akan memberikan hasil positif atau negatif dalam berperilaku.

2. Normatif beliefs yaitu mengacu pada ekspektasi perilaku yang dirasakan dari rujukannya baik individu atau kelompok, seperti keluarga, teman, pasangan, rekan kerja dan motivasi untuk mematuhi setiap individu atau kelompok tersebut. Hasil dari harapan normatif dan motivasi ini membentuk variabel norma subjektif. Norma subjektif adalah tekanan sosial yang dirasakan untuk terlibat atau tidak terlibat dalam berperilaku.

3. Control beliefs yaitu keyakinan seseorang atas kemampuan mengendalikan perilaku dan keyakinan individu akan adanya hambatan atau dukungan dalam berperilaku. Hasilnya membentuk kontrol perilaku yang dipersepsikan.

\section{Kekuasaan}

Pada hubungan antara manusia maupun antar kelompok sosial selalu terdapat pengertian mengenai kekuasaan dan wewenang. Terdapat perbedaan pengertian antara kekuasaan dan wewenang. Kekuasaan adalah setiap kemampuan untuk mempengaruhi pihak lain, sedangkan wewenang adalah kekuasaan yang ada pada seseorang atau sekelompok orang, yang mempunyai dukungan atau mendapat pengakuan dari masyarakat (Soekanto ,1982).

Sumber yang menjadi seseorang atau sekelompok kecil orang berkuasa atas orang lain pada penelitian ini adalah pengetahuan/informasi. Haryatmoko (2014) mengungkapkan kekuasaan tidak bisa dipisahkan dari pengetahuan. Kekuasaan dilaksanakan melalui manajemen: manajemen energi, kemampuan dan kehidupan masyarakat di mana pengetahuan adalah landasannya, bukan melalui perjuangan, pembatasan atau larangan. Wawancara, jajak pendapat, tes, konsultasi menjadi cara untuk menggapai kebenaran yang merupakan hasil dari kekuasaan. Pengetahuan tidak bersumber pada subjek, tetapi dalam hubungan kekuasaan.

Kekuasaan yang berhubungan dengan pengetahuan adalah teori kekuasaan Foucault. Foucault (1980) dalam Maring (2010) menjelaskan bahwa kekuasaan merupakan strategi yang dijalankan pihak tertentu dengan tujuan mendorong pihak lain untuk patuh atau taat, atau membuat pihak lain memberi dukungan terhadap pihak lain. Hal ini didukung dengan pernyataan Foucault dalam Ritzer dan Goodman (2010) mengenai kekuasaan. Foucault mengemukakan bahwa kekuasaan berada dalam berbagai jenis lingkungan mikro tidak terletak pada satu sumber sentral. Hayatmoko (2014) mengungkapkan cara Foucault memahami kekuasaan sangat orisinal. Orisinalitas terletak dalam definisi kekuasaan, tujuan dan sasarannya, hubungan kekuasaan-pengetahuan, mekanisme dan teknik kekuasaan.

Kekuasaan menurut Foucault (2002) yaitu kekuasaan harus dianalisis sebagai sesuatu yang berputar, sesuatu yang hanya berfungsi dalam bentuk sebuah rantai bukan dianggap sebagai fenomena dari konsolidasi oleh suatu individu yang membuat dominasi homogen atas individuindividu lainnya atau satu kelompok atau kelas atas kelompok atau kelas lainnya. Kekuasaan sedang bekerja ketika terdapat aturan-aturan, sistem regulasi, ada manusia yang mempunyai hubungan tertentu satu sama lain sehingga kekuasaan tidak pernah ditempatkan di sini atau di sana dan tidak dapat dianggap sebagai komoditas. Tidak hanya individu yang memutar kekuasaan ini tetapi di antara mereka karena mereka semua selalu berada dalam posisi yang secara serentak menjalankan dan melakukannya. Dengan kata lain, individu- individu yang berfungsi sebagai roda- 
roda kekuasaan bukan hanya menjadi titik-titik aplikasinya. Selain itu, Foucault (2002) juga mengungkapkan bahwa setiap individu memiliki kekuasaan di dalam tubuhnya masing-masing.

Konsep mengenai kekuasaan merupakan kontribusi Foucault terhadap pengaruh kekuasaan terhadap perilaku unjuk rasa. Foucault (1998) dalam Astuti (2013) memaparkan empat karakteristik utama kekuasaan. Pertama, Foucault berargumentasi bahwa kekuasaan ada dimana-mana dan terwujud dalam berbagai pihak, diskursus, agensi dan institusi. Kekuasaan tidak hanya berada di tangan para penguasa. Foucault menghindari penjelaskan kekuasaan yang selalu melihat hubungan antara kekuasaan dan negara, atau datang dari satu arah, atau selalu datang dari atas atau bawah (Foucault, 1980 dalam Maring, 2010). Foucault menekankan bahwa kekuasaan tidak hanya dioperasikan dari atas (top down), tetapi juga dari bawah (bottom-up). Foucault juga memandang bahwa kuasa sebagai hal yang melekat pada relasi sosial di antara anggota masyarakat.

Kedua, Foucault menentang konsep biner kuasa, dia tetap mengakui adanya struktur hegemoni. Ketiga, kekuasaan Foucault adalah pengakuannya tentang resistensi atau perlawanan. Foucault menyebutkan bahwa ketika ada kekuasaan, maka akan selalu ada resistensi. Tetapi, Foucault menggarisbawahi bahwa resistensi tidak bisa dilihat sebagai bagian terpisah dari kekuasaan, melainkan sebagai salah satu komponen yang bertujuan mentransformasi dan membentuk ulang kekuasaan yang diterapkan secara berbeda. Haryatmoko (2014) juga mengungkapkan di mana ada afirmasi kekuasaan, selalu ada perlawanan. Perlawanan bukan dalam arti kekuatan dari luar atau yang berseberangan, melainkan karena adanya kekuasaan itu sendiri. Keempat, kekuasaan bersifat dinamis dan tidak bisa diasosiasikan sebagai orang tertentu saja, sehingga kekuasaan sangat bergantung pada dinamika relasi sosial masyarakat.

Pada pencapaian tujuan kekuasaan terlihat dalam strategi yang dijalankan. Strategi kekuasaan yang dijalankan bisa melalui penindasan dan represi, juga dapat melalui cara yang persuasif dan normalisasi. Maring (2010) mengungkapkan jika mengikuti kerangka pikir Foucault tekanan startegi kekuasaan adalah pada mekanisme sosial yang persuasif, membujuk dan meyakinkan.

\section{Kerangka Pemikiran}

Industri PCI hadir di Kabupaten Bojonegoro pada tahun 2002 dan memperluas wilayah kerjanya pada tahun 2007. Kehadiran Industri PCI di pedesaan menimbulkan permasalahan sosial bagi warga desa yang berada disekitar wilayah kerja industri tersebut. Penelitian mengenai pengaruh kekuasaan terhadap perilaku unjuk rasa masyarakat di sekitar Industri PCI dilatarbelakangi permasalahan sosial yaitu warga desa melakukan unjuk rasa ketika ada aktivitas di Industri PCI. Oleh karena itu, akan dilihat bagaimana peluang bekerja di Industri PCI bagi warga desa dan warga desa dapat memanfaatkan peluang usaha setelah adanya Industri PCI disekitar tempat tinggal mereka. Timbulnya perbedaan kesempatan dalam mengakses pekerjaan di Industri PCI dan memanfaatkan peluang usaha dengan hadirnya Industri PCI akan mempengaruhi sikap warga desa. Sikap warga desa terhadap peluang bekerja di Industri PCI yang hadir di tengah-tengah mereka akan mendorong munculnya konflik antara warga desa dengan industri tersebut dalam bentuk perilaku unjuk rasa. Sikap akan muncul dipengaruhi oleh behavioral beliefs.

Behavioral beliefs akan mengarahkan pada konsekuensi tertentu dan evaluasi seseorang terhadap perilaku yang akan dilakukan. Perilaku ini tidak hanya dipengaruhi oleh sikap saja tetapi juga ada norma subjektif, kontrol perilaku yang dipersepsikan untuk berniat melakukan unjuk rasa kepada Industri PCI. Norma subjektif menyangkut perkiraan individu akan persetujuan orang yang "dihormatinya" terhadap perilaku yang akan ditampilkannya. Dalam hal ini tampak bahwa perilaku individu dipengaruhi juga oleh harapan orang lain yang dianggap "superior" daripada individu tersebut. Sebelum munculnya norma subjektif, individu tersebut dipengaruhi oleh normatif beliefs. Normatif beliefs adalah kepercayaan individu yang dimiliki mengenai ekspektasi perilaku yang dirasakan dari rujukannya baik itu individu atau kelompok. Tampak ada "kekuasaan" tertentu dari seseorang atau sekelompok orang terhadap individu sehingga individu terpengaruh atau kuasa yang dimiliki seseorang tersebut.

Kontrol perilaku yang dipersepsikan merupakan persepsi terhadap kesulitan sebuah perilaku untuk dan dilaksanakan. Kontrol perilaku yang dipersepsikan ini merefleksikan pengalaman masa lalu dan antisipasi terhadap hambatan yang mungkin terjadi ketika melakukan sebuah perilaku. Sebelum kontrol perilaku yang dipersepsikan terjadi terdapat control beliefs. Control beliefs adalah keyakinan individu dalam mengendalikan perilaku akan adanya hambatan atau dukungan dalam berperilaku. Bisa dikatakan kontrol perilaku yang dipersepsikan adalah kemampuan individu dalam melakukan tindakan

Ketiga variabel (sikap, norma subjektif dan kontrol perilaku yang dipersepsikan) tidak berjalan sendirisendiri, mereka saling mempengaruhi untuk memunculkan rasa niat melakukan unjuk rasa kepada Industri PCI.

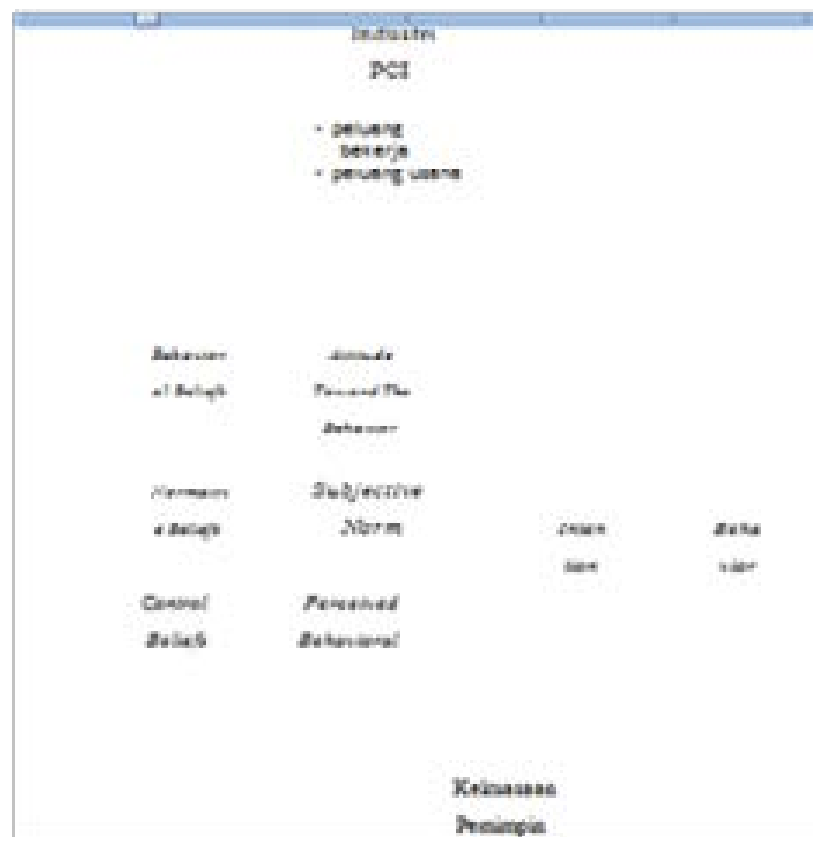

Gambar 2 . Pengaruh Kekuasaan terhadap Perilaku Unjuk Rasa Masyarakat di Sekitar Industri Ekstraktif Minyak Bumi 


\section{Hipotesis}

Penyusunan hipotesis dalam penelitian ini adalah untuk mengarahkan dalam proses menjawab permasalahan penelitian dan untuk memudahkan dalam proses mencapai tujuan penelitian yang telah dibuat. Hipotesis dalam penelitian ini adalah:

1. Sikap warga desa, norma subjektif dan kontrol yang dipersepsikan warga desa berpengaruh secara signifikan terhadap kecenderungan warga desa berperilaku unjuk rasa.

2. Kekuasaan pemimpin lokal mempengaruhi perilaku unjuk rasa.

\section{PENDEKATAN LAPANG}

\section{Lokasi dan Waktu Penelitian}

Penelitian dilaksanakan di dua kecamatan yaitu di Kecamatan Kapas dan Kecamatan Bojonegoro terutama dua desa yang menjadi lokasi eksploitasi dan lokasi wilayah kerja Industri PCI. Selain itu desa ini dipilih karena masyarakat di kedua desa melakukan aksi unjuk rasa terhadap Industri PCI berdasarkan informasi yang didapatkan sebelumnya dari berbagai media tentang dampak eksploitasi minyak bumi di Bojonegoro.

Dua desa yang menjadi lokasi pengeboran Industri PCI yaitu PAD A terletak di Desa Campa dan PAD B terletak di Desa Pelenggo. Kedua Desa ini merupakan desa penghasil minyak berdasarkan Peraturan Bupati Bojonegoro Nomor 47 Tahun 2010 tentang pedoman penetapan alokasi dana desa proporsional berdasarkan koefisien variabel kawasan di Kabupaten Bojonegoro. Berdasarkan pada strategi penelitian ini, maka lokasi penelitian dilakukan pada warga desa yang mewakili dan memiliki karakteristik dalam pemasalahan penelitian yang telah dibuat sebelumnya.

Lokasi penelitian dipilih secara sengaja, karena di sekitar tempat tinggal warga desa terdapat perusahaan multinasional yang bergerak di bidang eksploitasi sumber daya minyak bumi. Dengan mengambil kedua desa konsesi perusahaan tersebut sebagai lokasi penelitian, peneliti berharap dapat menemukan jawaban dari pertanyaan-pertanyaan penelitian. Penelitian lapang dilakukan mulai bulan Agustus - Oktober 2013 dan bulan April - Mei 2014.

\section{Teknik Pengumpulan Data}

Metode yang digunakan dalam penelitian ini adalah metode kuantitatif yang didukung oleh data kualitatif. Metode kuantitatif salah satunya adalah survei yang secara umum berhubungan dengan pengumpulan opiniopini, preferensi (pilihan-pilihan), dan persepsi-persepsi dari suatu fakta, dengan memakai daftar pertanyaan tertulis atau interview(Muljono, 2012). Metode kuantitatif dalam penelitian ini untuk menganalisis sikap warga desa terhadap kehadiran Industri PCI dengan dimensi peluang bekerja. Selain sikap terdapat norma subjektif, kontrol perilaku yang dipersepsikan dan perilaku unjuk rasa. Metode survei dibantu dengan kuesioner.

Data yang dikumpulkan adalah data kualitatif dan data kuantitatif. Data kualitatif dengan melakukan pengamatan (observasi) dan wawancara mendalam (in depth intervew).
Wawancara mendalam dilakukan kepada informaninforman yang dapat menjawab rumusan masalah pada penelitian ini. Informan diambil dari masyarakat desa, informan dari pihak perusahaan, informan kunci yang ada di desa dan lembaga-lembaga terkait yang dapat membantu pada pencarian informasi. Wawancara mendalam terhadap informan kunc dengan menggunakan teknik bola salju (snow ball). Data kuantitatif memakai kuesioner yang diambil dari dua desa dengan jumlah 100 responden. Responden dibagi menjadi dua yaitu responden yang tidak ikut unjuk rasa dan responden yang ikut unjuk rasa.

\section{Teknik Analisis Data}

Teknik analisis data yang dilakukan adalah analisis data kualitatif dan kuantitatif. Data kualitatif baik data primer maupun sekunder yang telah didapatkan akan diolah menggunakan tiga tahap kegiatan analisis data. Sitorus (1998) mengatakan bahwa dalam menganalisis data dilakukan secara bersama yaitu reduksi, penyajian data dan penarikan kesimpulan. Reduksi data bertujuan menajamkan, menggolongkan, mengarahkan, mengeliminasi data yang tidak diperlukan dan mengorganisir data sehingga didapatkan kesimpulan. Data yang sudah direduksi akan disajikan dalam bentuk deskripsi maupun matrik dan diharapkan dapat menjawab perumusan masalah yang telah ditetapkan kemudian menarik kesimpulan dari data primer dan sekunder yang telah direduksi.

Pada data kuantitatif dilakukan dengan mengelompokkan jawaban responden yang kemudian disajikan dalam bentuk tabulasi silang. Data kuantitatif menggunakan kuesioner dengan pertanyaan dalam kuesioner ditujukan untuk mendapatkan data tentang sikap terhadap hadirnya Industri PCI dengan dimensi peluang bekerja di dalam Industri PCI, norma subjektif untuk berperilaku unjuk rasa, kontrol perilaku yang dipersepsikan dan niat berperilaku unjuk rasa. Skala pengukuran yang digunakan merupakan skala likert dengan data ordinal. Data kuantitatif yang didapatkan dari kuesioner sebelumnya dilakukan pengkodean data. Kemudian diskoring dibuat secara konsisten, semakin tinggi skor maka akan semakin tinggi kategorinya. Menguji pengaruh sikap, norma subjektif dan kontrol perilaku yang dipersepsikan terhadap niat menggunakan regresi linier berganda (multiple regression), sedangkan untuk melihat perbedaan sikap, norma subjektif, dan kontrol perilaku yang dipersepsikan antara responden yang ikut dan tidak ikut unjuk rasa mengguakan uji-t. Kedua uji statistik ini menggunakan software SPSS for Windows Versi 16.0.

\section{HASIL PENELITIAN}

\section{Akar Masalah Timbulnya Unjuk Rasa Warga Desa}

\section{Terhadap Industri PCI}

Salah satu permasalahan dengan keberadaan Industri PCI disekitar tempat tinggal warga Desa Campa dan Desa Pelenggo adalah kurangnya peluang bekerja di sana. Sebelum Industri PCI melakukan aktivitasnya di dua desa tersebut terdapat perjanjian dengan warga desa secara lisan. Isi perjanjian itu adalah warga desa yang sawahnya terkena pembebasan, maka anaknya dapat bekerja di Industri PCI. Hal ini dilakukan supaya warga desa yang terkena pembebasan lahan tidak kehilangan pekerjaannya. Pada 
perjanjian tersebut tidak ada penentuan berapa persen warga desa yang dapat bekerja di PCI sehingga dibuat kesepakatan bersama diantara tiga desa (Desa Campa, Desa Pelenggo dan Desa Sambiroto). Isi dari kesepakatan adalah jika aktivitas ada di Industri PCI PAD A yang bertempat di Desa Campa, maka warga Desa Campa mendapatkan kesempatan kerja sebesar 65 persen dari jumlah pekerja yang dibutuhkan, Desa Pelenggo 20 persen dan Desa Sambiroto 15 persen. Jika aktivitas ada di Industri PCI PAD B yang berada di Desa Pelenggo, maka warga Desa Pelenggo mendapatkan kesempatan kerja sebesar 65 persen, Desa Campa 20 persen dan Desa Sambiroto 15 persen.

Ada tiga jenis pekerjaan di Industri PCI yang diumumkan untuk warga desa diantaranya (1) tenaga kerja skill adalah tenaga kerja yang memang memiliki skill di bidang perminyakan dan sudah memiliki pengalaman. Biasanya berasal dari perekrutan yang diadakan oleh Petrochina dan Pertamina sendiri, (2) tenaga kerja skill temporer adalah tenaga kerja yang memiliki skill tetapi tidak tetap dan (3) tenaga kerja non skill temporer adalah tenaga kerja yang tidak memiliki skill dan tidak tetap. Tenaga kerja non skill temporer yang dapat diakses oleh warga desa dan status pekerjaannya adalah outsourcing. Pada jalur perekrutan tenaga kerja di Industri PCI terdapat perbedaan antara Desa Pelenggo dan Desa Campa. Pada Desa Pelenggo jalur perekrutan tenaga kerja melalui jalur resmi yaitu berpusat pada pemerintah desa yang dapat dilihat pada Gambar 3. Terlihat bahwa pemerintah desa memiliki kekuasaan pada perekrutan tenaga kerja karena pemerintah desa yang menyeleksi warganya untuk bekerja di Industri PCI PAD B. Pada jalur resmi dilakukan dengan cara pemerintah desa diberi surat dari Industri PCI yang isinya akan dilakukan pengeboran sehingga membutuhkan tenaga kerja lokal. Pemerintah desa akan meneruskan informasi tersebut kewarganya melalui ketua RT. Setelah warga desa mendaftar melalui pemerintah desa, maka dilakukan proses seleksi dengan sistem undian dan semua warga desa yang mendaftar menyaksikan proses tersebut. Warga desa yang lolos dalam undian maka dialah yang diterima dengan sistem kontrak.

\section{Pemerintah $\quad$ Setiap RT di}

\section{Desa}

Seleksi

dengan sistem

Lolos diterima

dengan sistem

kontrak

Gambar 3. Proses perekrutan tenaga kerja di Desa Pelenggo

Pada Desa Campa ada dua jalur dalam perekrutan tenaga kerja di industri PCI yaitu jalur resmi dan jalur tidak resmi yang dapat dilihat pada Gambar 7. Jalur resmi yang ada di Desa Campa terjadi seperti yang ada di Desa Pelenggo. Pada jalur yang tidak resmi melalui kerabat atau keluarga yang sudah bekerja di Industri PCI, misalnya memiliki kerabat atau keluarganya bekerja sebagai koordinator satpam, jika ada lowongan maka akan mengajak keluarga atau kerabatnya untuk bekerja bersama dia. Ada juga dengan cara membeli pekerjaan (berkisar Rp 500000 s/d Rp 4000000) kepada koordinator perekrutan tenaga kerja. Jika warga sudah membayar maka mereka diterima bekerja di Industri PCI karena manajemen Industri PCI bisa menerima karyawan jika ada rekomendasai dari tokoh masyarakat tersebut. Tokoh masyarakat ini diibaratkan sebagai pintu masuk untuk bekerja di industri tersebut. Hal ini diungkapkan oleh tokoh pemuda INDR dan ketua Linmas Desa Campa (Pak KMD) bahwa di Desa Campa ada lowongan pekerjaan yang dijual, dengan cara membayarar kepada pekerja yang ada di dalam Industri PCI.

Selain itu ada jalur yang tidak resmi yang melalui kerabat yang bekerja di Industri PCI, caranya yaitu ada tokoh pemuda yaitu SYK yang sudah bekerja di Industri PCI dan dia juga selalu ikut di dalam aksi unjuk rasa. SYK tidak memiliki jabatan di Industri PCI, namun dia sering melakukan aksi dan selalu merasa tidak adil jika ada orang lain yang masuk dan posisinya dapat diisi oleh warga Desa Campa tetapi warga desa sendiri tidak bisa masuk. SYK akan mencari managernya dan menayakan hal tersebut. SYK tidak peduli apa alasan dari managernya. Akhirnya SYK ini diberikan kesempatan untuk memasukkan dua orang untuk bekerja di industri tersebut.

\section{Jalur dalam perekrutan tenagga ketja di Desa}

Jalur tesmi

Pentetinte desa

\section{Jalur tidak}

\section{- Reluargakerabat yang bekerja d Isdustri PCI \\ - Membeli pekerian di lndustri PCI}

Gambar 4. Jalur perekrutan tenaga kerja di Desa Campa

Tabel 1. Jumlah dan persentase responden yang ikut unjuk rasa berdasarkan sumber informasi lowongan kerja di Industri PCI

\begin{tabular}{|c|c|c|}
\hline \multicolumn{3}{|c|}{ Sumber infromasi lowongan Sast ini } \\
\hline \multirow[t]{2}{*}{ kerja di Indestri PCI } & bekerja & Tidak beketja \\
\hline & a $\%$ & n $\%$ \\
\hline Pemserintah desa Orang & 960.0022 & 52.16 \\
\hline $\begin{array}{l}\text { daluen di frolusiti PCT } \\
\text { Koluarg }\end{array}$ & 533.331 & 2.33 \\
\hline Teman & 1000001 & 233 \\
\hline $\begin{array}{l}\text { Tidak meedapatkan } \\
\text { Informasi }\end{array}$ & $0 \quad 00.0017$ & 40.85 \\
\hline TOTAL & 1510000.43 & 100.00 \\
\hline
\end{tabular}

Sumber informasi lowongan pekerjaan di Industri PCI yang didapatkan oleh responden yang unjuk rasa dapat dilihat pada Tabel 1. Terlihat bahwa responden yang saat ini bekerja dan tidak bekerja di Industri PCI mendapatkan 
informasi lowongan pekerjaan dari pemerintah desa sebesar 60.00 persen dan 52.16 persen. Namun terdapat 33.33 persen responden yang saat ini bekerja Industri PCI dan 2.33 persen responden yang tidak bekerja di sana mendapatkan informasi dari orang dalam di Industri. Selain itu, ada 40.85 persen responden yang tidak bekerja tidak mendapatkan informasi mengenai hal tersebut. Hal ini terlihat bahwa informasi mengenai lowongan pekerjaan tidak terpusat kepada pemerintah desa dan tidak tersebar ke seluruh warga desa karena masih ada warga desa yang tidak mendapatkan informasi mengenai lowongan pekerjaan di Industri PCI.

Jika melihat jumlah dan persentase responden yang ikut unjuk rasa berdasarkan hubungan kerja dengan Industri PCI dapat dilihat pada Tabel 2. Terlihat bahwa dari seluruh responden yang unjuk rasa sedangkan 41.38 persen tidak pernah bekerja sama sekali di Industri PCI.

Tabel 2. Jumlah dan persentase responden yang ikut unjuk rasa berdasarkan hubungan kerja dengan Industri PCI

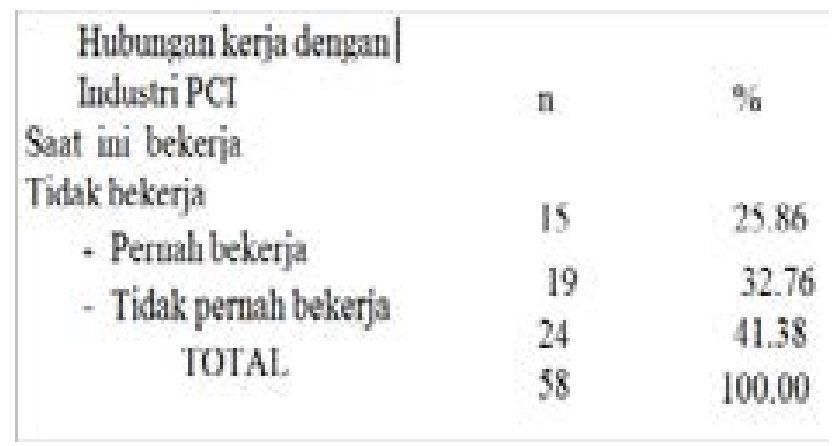

Ada beberapa persyaratan untuk bekerja di Industri PCI diantaranya warga desa harus memiliki usia angkatan kerja, minimal memiliki ijasah SMA, surat lamaran pekerjaan, fotokopi ijazah pendidikan terakhir, fotokopi kartu tanda penduduk, fotokopi kartu keluarga, foto diri dan rekomendasi dari kepala desa.

Tabel 3. Jumlah dan persentase tingkat pendidikan responden berdasarkan hubungan kerja dengan Industri PCI

\begin{tabular}{|lcccc}
\multicolumn{1}{c}{ Tingkat } & \multicolumn{2}{c}{ Sat ini bekcrja } & \multicolumn{2}{c}{ Tidak bekcrja } \\
pesdidikan & II & $\%$ & II & $\%$ \\
SMAkc atas & & & & \\
SMP & 8 & 53.33 & 28 & 65.12 \\
& 4 & 26.67 & 6 & 13.95 \\
SD & 3 & 20.00 & 9 & 20.93 \\
TOTAL. PCI. 15 & 100.00 & 43 & 100.00
\end{tabular}

Tingkat pendidikan responden yang ikut unjuk rasa dapat dilihat pada Tabel 3. Terlihat bahwa hampir secara keseluruhan responden tingkat pendidikannya adalah lulusan SMA ke atas baik yang saat ini bekerja (53.33 persen) dan tidak bekerja (65.12 persen) di Industri PCI . Namun terdapat 20.00 persen lulusan SD yang bekerja di Industri PCI.

Hal ini dilakukan sebagai bentuk kompensasi Industri PCI kepada warga desa yang rumahnya dekat dengan lokasi karena selalu mendengarkan kebisingan dan debu akibat dari keluar masuk kendaraan dari lokasi pengeboran. Tugas mereka hanya memberikan tanda bahwa ada kendaraan yang sedang keluar atau masuk ke lokasi. Pekerjaan tersebut pemerintah desa menyebutnya sebagai "klebet".

Tuntutan yang pernah dilakukan responden unjuk rasa pada Industri PCI ada tiga yaitu peluang bekerja, dana CSR, dan ganti rugi yang dapat dilihat pada Tabel 4. Responden dapat memilih jawaban lebih dari satu tuntutan. Terlihat bahwa tuntutan responden yang unjuk rasa paling banyak menjawab mengenaipeluang bekerja di Industri PCI sebesar 87.93 persen. Jika dilihat berdasarakan hubungan kerja dengan Industri PCI, responden yang saat ini bekerja di Industri PCI tuntutan yang dilakukan yaitu peluang bekerja dan dana CSR sedangkan responden yang saat yang ikut unjuk rasa berdasarkan hubungan kerja dengan Industri PCI dapat dilihat pada Tabel 2. Terlihat bahwa dari seluruh responden yang unjuk rasa terdapat 25.86 persen yang saat ini bekerja di Industri PCI dan 74.14 persen yang saat ini tidak bekerja di Industri PCI. Namun dari yang disebutkan terakhir ini terdapat 32.76 persen pernah bekerja di Industri PCI ini tidak bekerja di Industri PCI lebih menuntut peluang bekerja dan dana ganti rugi.

Tabel 4. Jumlah dan persentase jawaban responden unjuk rasa berdasarkan tuntutan yang pernah dilakukan

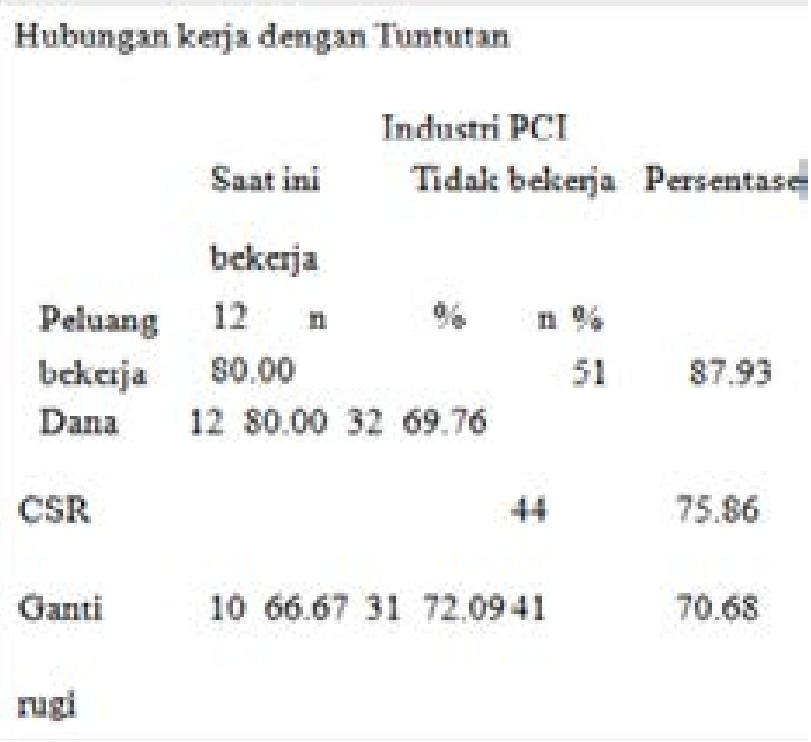

Unjuk rasa mengenai peluang bekerja di Industri PCI disebabkan karena pekerjaan yang dapat dilakukan oleh warga desa diduduki oleh warga desa lain. Warga desa dapat mengetahui hal tersebut jika Industri PCI ada aktivitas, jika tidak ada aktivitas warga desa tidak dapat mengetahui siapa saja yang bekerja di dalam industri tersebut. Ini yang menimbulkan rasa iri di dalam diri warga desa sehingga mereka melakukan unjuk rasa dengan cara memblokade jalan utama menuju lokasi pengeboran. Aksi unjuk rasa mengenai tuntutan lapangan pekerjaan di Industri PCI digerakkan oleh ketua RW (Pak IM) dan ketua 
Linmas (Pak KMD).

Tuntutan mengenai dana CSR disebabkan karena Industri PCI tidak transparan mengenai hal tersebut dan dana yang diturunkan tidak sesuai dengan waktu yang telah dijanjikan oleh Industri PCI. Unjuk rasa mengenai tuntutan dana CSR digerakan oleh Kepala Desa Pelenggo dan ketua RW (Pak IM). Tuntutan mengenai ganti rugi lingkungan dilakukan jika Industri PCI tidak memberikan tali asih kepada warga desa pada saat industri tersebut ada aktivitas. Tuntutan ini digerakkan oleh Kepala Desa Pelenggo dan ketua RW (Pak IM).

Keberadaan Industri PCI Menimbulkan Sikap Tertentu Warga Desa Untuk Berperilaku Unjuk Rasa

Keberadaan Industri PCI di Desa Campa dan Desa Pelenggo menimbulkan permasalahan sosial bagi warga desa yang berada disekitar wilayah kerja industri tersebut. Permasalahan sosial yaitu warga desa melakukan unjuk rasa ketika ada aktivitas di Industri PCI terutama mengenai tuntutan lapangan pekerjaan untuk warga desa. Untuk melihat hal tersebut maka akan melihat bagaimana sikap warga desa dalam mempengaruhi perilaku unjuk rasa yang dilakukan warga desa kepada Industri PCI menggunakan teori perilaku terencana (theory of planned behavior) dengan 100 responden yang dibagi menjadi dua yaitu responden yang ikut unjuk rasa dan responden yang tidak ikut unjuk rasa. Terdapat beberapa variabel yang digunakan untuk melihat pengaruh sikap pada perilaku unjuk rasa warga desa pada Industri PCI dilihat dari sikap warga desa mengenai hadirnya Industri PCI, norma subjektif yang warga desa dirasakan untuk berperilaku unjuk rasa, kontrol perilaku yang dirasakan, niat untuk melakukan unjuk rasa dan perilaku unjuk rasa.

Jika melihat sikap responden berdasarkan hubungan kerja di Industri PCI dapat dilihat pada Tabel 6. Telihat bahwa responden yang ikut unjuk rasa dan tidak ikut unjuk rasa yang hubungan kerja dengan Industri PCI yaitu tidak bekerja di sana memiliki sikap lebih negatif sebesar 58.13 persen dan 57.14 persen sedangkan responden yang saat ini bekerja memiliki sikap lebih positif dengan hadirnya Industri PCI sebesar 73.00 persen dan 100.00 persen.

Tabel 6. Jumlah dan persentase hubungan kerja di Industri PCI responden berdasarkan

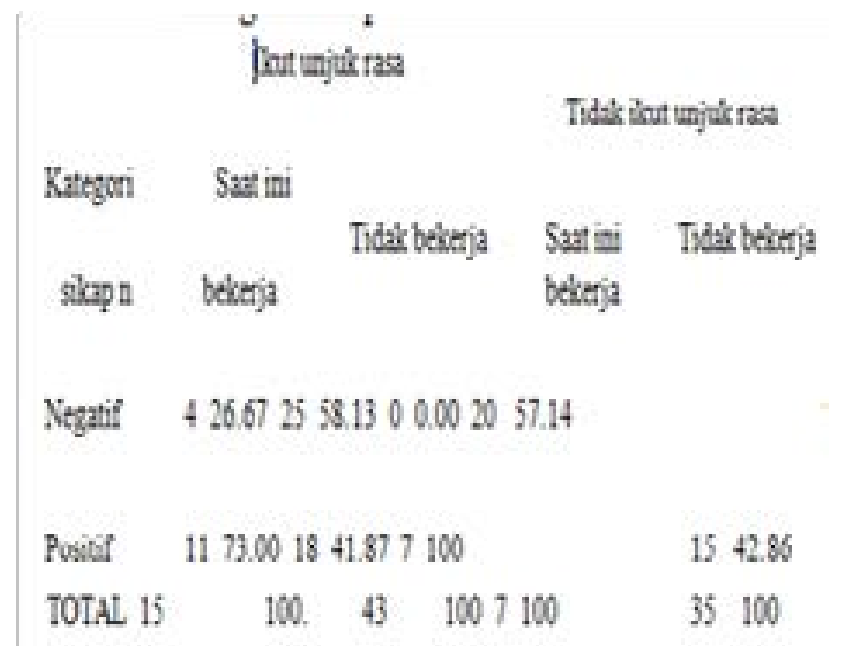

\section{Norma Subjektif Warga Desa Rasakan untuk Berperilaku Unjuk Rasa}

Norma subjektif pada penelitian ini adalah kekuatan pengaruh orang atau faktor lain di lingkungannya yang dianggap memotivasi responden untuk melakukan atau tidak melakukan unjuk rasa.

Dukungan sosial yang kuat akan menunjukan bahwa sumber dukungan tersebut sangat dirasakan pengaruhnya bagi responden untuk melakukan unjuk rasa dapat dilihat pada Tabel 7. Terlihat bahwa responden yang ikut unjuk rasa baik yang saat ini bekerja dan tidak bekerja di Industri PCI memiliki dukungan sosial yang rendah sebesar 60.00 persen dan 58.14 persen. Hal ini menunjukkan bahwa dukungan untuk melakukan unjuk rasa tidak dirasakan oleh responden.

Pada Tabel 7 menunjukkan bahwa norma subjektif yang dirasakan oleh responden yang ikut unjuk rasa rendah. Namun, jika dilihat dari alasan responden melakukan aksi unjuk rasa, apakah diajak teman, ikut-ikutan, atas kemauan sendiri, diperintah

Tabel 7. Jumlah dan persentase responden yang ikut unjuk rasa berdasarkan kategori norma subjektif yang mendukung unjuk rasa

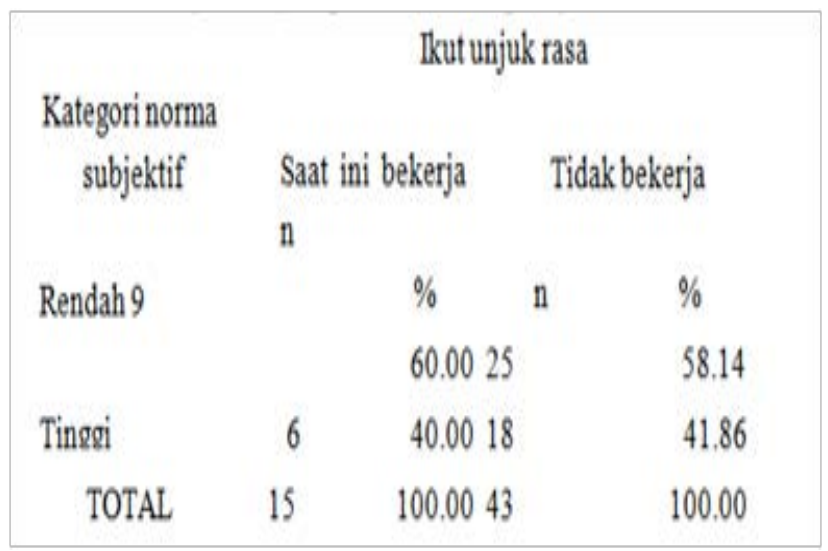

berkomunikasi dengan responden yang lainnya.

Tabel 8. Jumlah dan persentase responden yang ikut unjuk rasa berdasarkan alasan melakukan unjuk rasa

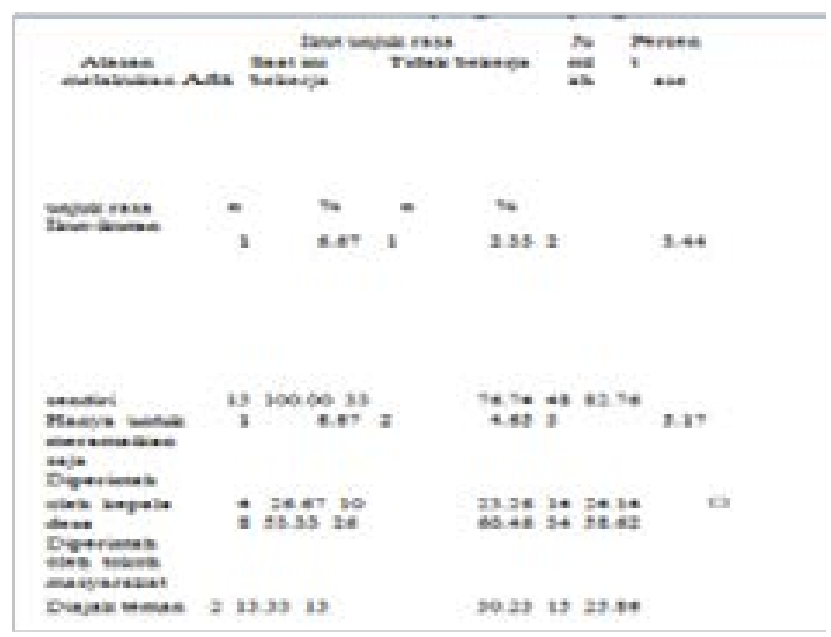


Hal ini merupakan salah satu kelemahan dari penelitian kuantitatif diberikan kepada komunitas yang sama. Pada responden yang tidak bekerja lebih diperintah oleh orang lain. Hal ini dapat dikatakan, walaupun tidak mendapatkan dukungan dari orang atau faktor lain di lingkungannya yang dianggap memotivasi responden untuk melakukan unjuk rasa ternyata responden melakukan unjuk rasa atas sendiri dan juga perintah dari tokoh masyarakat. Disini terlihat ada kekuasaan yang mempengaruhi responden untuk melakukan aksi unjuk rasa ke Industri PCI.

\section{Kontrol Perilaku yang Dipersepsikan Warga Desa untuk Bereprilaku Unjuk Rasa}

Kontrol perilaku yang dipersepsikan pada peneilitian ini mengenai kemampuan responden untuk menerima konsekuensi ketika melakukan unjuk rasa. Pada penelitian ini melihat bagaimana keyakinan warga desa akan kemampuannya untuk melakukan kemampuannya warga desa ada tujuh komponen pada kontrol perilaku yang dirasakan diantaranya: oleh kepala desa, diperintah oleh tokoh masyarakat, atau hanya untuk meramaikan saja dapat dilihat pada Tabel 8 . Pada Tabel 8 dibuat berdasarkan masing- masing .

Tabel 9. Jumlah dan persentase responden yang ikut unjuk rasa berdasarkan kontrol perilaku yang dipersepsikan

\begin{tabular}{|c|c|c|c|}
\hline Kategori kontrol perilaku & \multicolumn{3}{|c|}{$\begin{array}{l}\text { Ilut unjuk rasa yang } \\
\text { Saat ini bekerja Tidak bekerja }\end{array}$} \\
\hline \multicolumn{2}{|c|}{ Tidak dapat mengontrol Dipersepsikan } & $n 1$ & $\% \quad n$ \\
\hline & 6.67 & 0 & 0.00 \\
\hline Dapatmengontrol & 1473.33 & 431 & 0.00 \\
\hline TOTAL & 15100.00 & 431 & \\
\hline
\end{tabular}

\section{Niat Melakukan Unjuk Rasa}

Ada dua komponen dalam memperlihatkan niat responden yang ikut unjuk rasa yaitu melakukan aksi unjuk rasa walaupun tidak mendapatkan izin dari aparat kepolisian dan pemerintah desa. Niat untuk melakukan unjuk rasa pada responden yang ikut unjuk rasa dapat dilihat pada Tabel 10. Terlihat bahwa seluruh responden tidak memiliki niat untuk melakukan unjuk rasa. Namun, jika dilihat pada kategori cukup memiliki niat responden yang bekerja di Industri PCI lebih memiliki cukup niat dibandingkan responden yang tidak bekerja disana. Hal tersebut juga diungkapkan oleh salah satu tokoh masyarakat bahwa izin dari kepolisian dan pemerintah desa itu penting, jika tidak mendapatkan izin dari mereka maka aksi unjuk rasa tidak akan dilakukan.

Dari uraian mengenai sikap, norma subjektif dan kontrol perilaku yang dipersepsikan dapat dikatakan bahwa pada theory of planned behavior menyatakan bahwa suatu perilaku yang akan dilakukan oleh seseorang yang dipengaruhi oleh niat, niat sendiri dipengaruhi oleh sikap, norma subjektif niat sendiri dipengaruhi oleh sikap, norma subjektif responden yang ikut unjuk rasa terlihat bahwa sikap responden yang saat ini bekerja di Industri PCI memiliki sikap lebih positif dengan hadirnya Industri PCI, sedangkan responden yang tidak bekerja memiliki sikap negatif.

Norma subjektif pada responden yang ikut unjuk rasa jika dilihat berdasarkan hubungan kerja di Industri PCI terlihat bahwa dukungan untuk melakukan unjuk rasa rendah. Walaupun dukungan yang dirasakan rendah, namun jika dilihat berdasarkan alasan mereka melakukan unjuk rasa karena kemauannya sendiri dan diperintah oleh tokoh masyarakat. Terlihat bahwa ada niat dari diri responden untuk melakukan unjuk dengan kontrol perilaku yang dipersepsikan responden yang ikut unjuk rasa terlihat bahwa kontrol responden yang saat ini bekerja di Industri PCI dan yang tidak bekerja disana memiliki kontrol yang lebih tinggi yang artinya responden mampu untuk mengontrol dan menerima konsekuensi ketika melakukan unjuk rasa.

Tabel 10. Jumlah dan persentase responden vang ikut 1 Variabel Independen Signifikan pada niat Hubungan antara Sikap, Norma Subjektif dan Niat
Melakukan Unjuk Rasa

Pada theory of planned behavior, niat pada seseorang menentukan apakah sebuah perilaku akan terjadi. Niat yang ada pada seseorang juga dipengaruhi oleh sikap, norma subjektif dan kontrol perilaku yang dipersepsikan. Hal ini dilihat pada responden yang ikut unjuk rasa. Jika di uji bersama-sama (sikap, norma subjektif dan kontrol perilaku yang dipersepsikan) menggunakan analisis ANOVA didapatkan p-value $=0.018$ kurang dari $\alpha=0.1$ yang artinya ketiga variabel tersebut memiliki pengaruh signifikan terhadap niat.

Pada penelitian ini menggunakan $\alpha=0.1$ karena penelitian sosial yang mana sangat sulit bagi peneliti untuk dapat mengontrol hasil yang sesuai dengan keinginan. Pada penelitian sosial yang diteliti adalah manusia yang bersifat mobile dan sangat mungkin terjadi pertukaran informasi, pengetahun dan atribut yang lainnya sehingga kemungkinan error yang terjadi cukup besar.

Jika diuji satu persatu (sikap, norma subjektif dan kontrol perilaku yang dipersepsikan) terhadap niat dapat dilihat pada Tabel 10. Terlihat bahwa sikap memiliki p-value $=0.511$ lebih dari $\alpha=0.1$ yang artinya sikap tidak berpengaruh signifikan terhadap niat. Sementara itu, pada norma subjektif dan kontrol perilaku yang dipersepsikan berperngaruh signifikan terhadap niat karena memiliki $\mathrm{p}$-value $=0.031$ dan $\mathrm{p}$ - value $=0.028$ kurang dari $\alpha$ atau 0.1 . Tabel 11 Hasil analisis regresi linier berganda untuk memprediksikan niat pada responden unjuk rasa $(n=58)$ rendah. Walaupun dukungan yang dirasakan rendah, namun jika dilihat berdasarkan alasan mereka melakukan unjuk rasa karena kemauannya sendiri dan diperintah oleh tokoh masyarakat. Terlihat bahwa ada niat dari diri responden 
untuk melakukan unjuk rasa dan juga ada kekuasaan yang mempengaruhi responden dalam melakukan aksi unjuk rasa. Selain itu juga didukung kekuasaan merupakan strategi yang dijalankan pihak tertentu dengan tujuan mendorong pihak lain untuk patuh atau taat, atau membuat pihak lain memberi dukungan terhadap pihak lain. Hal ini didukung dengan pernyataan Foucault dalam Ritzer dan Goodman (2010) mengenai kekuasaan. Foucault mengemukakan bahwa kekuasaan tidak terletak pada satu sumber sentral tetapi kekuasaan berada dalam berbagai jenis lingkungan mikro. Dalam memahami kekuasaan yang digunakan Foucault harus melihat definisi kekuasaan yang dibangun, tujuan dan sasaran kekuasaan, hubungan kekuasaan dan pengetahuan, mekanisme, strategi dan taktik kekuasaan (Haryatmoko 2014).

Pada ketokohan formal, lapisan atas merupakan warga desa yang memiliki jabatan di desa. Lapisan menengah digambarkan pada perangkat desa diantaranya Ketua RW, Ketua RT, Kepala Dusun. Lapisan bawah yaitu warga desa sendiri yang tidak memiliki jabatan di desa. Pada ketokohan informal

digambarkan pada orang yang memiliki pengaruh Pada lapisan sosial ketokohan formal ini sudah jelas bahwa mereka memiliki kekuasaan dan wewenang terutama yang ada pada lapisan atas. Hal ini dikarenakan mereka mempunyai jabatan yang disahkan melalui pearturanperaturan yang telah ditetapkan oleh pemerintah pusat. Pada lapisan menengah, mereka menjabat sebagai kepala dusun, Ketua RW dan Ketua RT ini hanya pengakuan dari warga sekitarnya. Tokoh masyarakat yang telah disebutkan diatas ternyata ada yang menjadi penggerakpenggerak warga desa untuk melakukan aksi unjuk rasa kepada Industri PCI.

Tabel 12. Keterlibatan dan peran aktor dalam aksi unjuk rasa di Desa Campa dan Desa

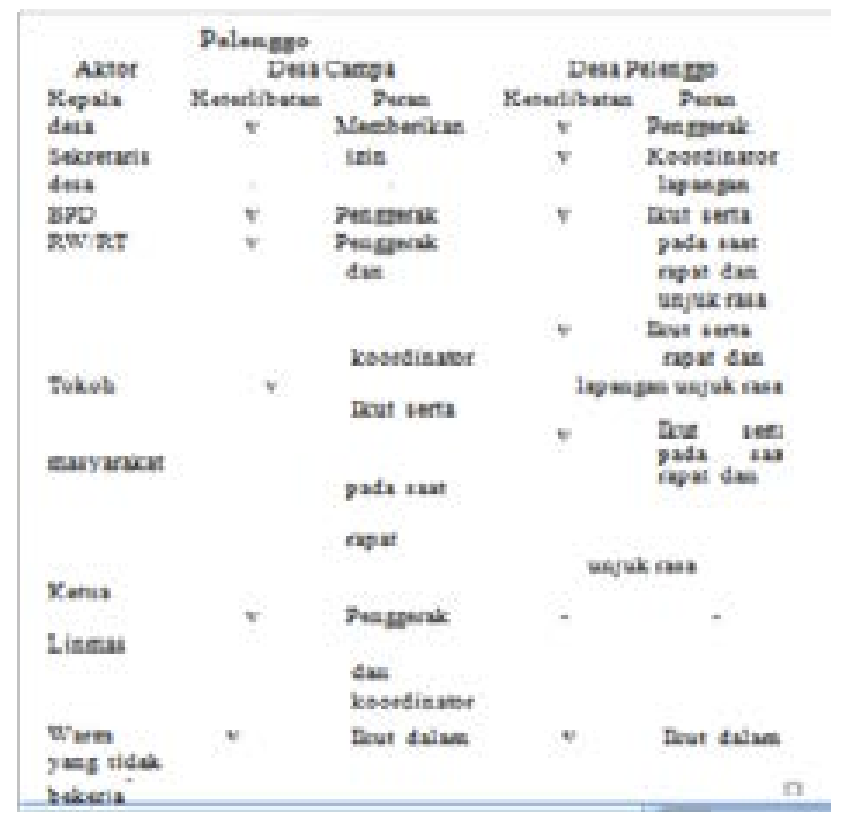

Ada beberapa tokoh masyarakat yang menggerakkan warga Desa Campa dan Desa Pelenggo untuk melakukan aksi unjuk rasa yang dapat dilihat pada Tabel 12. Terlihat bahwa masing-masing aktor mempunyai peran dan tujuan yang berbeda. Kepala Desa Pelenggo dan Ketua Linmas Desa Campa tujuannya untuk mempertahankan apa yang menjadi hak warga desa dengan keberadaan Industri PCI agar mereka jangan sampai hanya menjadi penonton dan hanya mendapatkan debu akibat dari keluar masuk kendaraan dari lokasi pengeboran. Selain itu agar dana kompensasi segera turun dan penambahan kompensasi dengan adanya perluasan wilayah kerja pengeboran baru di Desa Campa, dia dapat membedakan mana ujuan penggerak untuk kepentingan warga desa atau epentingan pribadi yang mendompleng pada kepentingan warga desa. supaya ikut adalah melalui rangsangan yaitu penyadaran warga desa dengan hadirnya Industri PCI.

Ada karakteristik yang dimiliki para penggerak aksi unjuk rasa. Kepala Desa Pelenggo memiliki latar belakang sebagai pengusaha. Warga Desa Pelenggo telah memberikan kepercayaan kepada Pak PJ untuk menjabat kembali sebagai kepala desa. Pada Ketua RW Desa Campa yang bernama Pak IM selain menjadi Ketua RW, dia juga sebagai tokoh agama yang aktif di Masjid Agung Kabupaten Bojonegoro, selain itu juga sebagai guru agama di salah satu Sekolah Dasar di Kabupaten Bojonegoro. Sedangkan pada Ketua Linmas Desa Campa memiliki latar belakang sebagai ketua perlindungan masyarakat selain itu dia juga sebagai pedagang, sehingga banyak berinteraksi dengan warga Desa Campa.

Pada Tabel 13 menunjukkan terdapat perbedaan mekanisme dan strategi yang dilakukan oleh setiap penggerak unjuk rasa karena tujuan mereka menggerakkan warga desa berbeda. Unjuk rasa ini tidak terjadi begitu saja. Sebelum melakukan unjuk rasa para penggerak melakukan diskusi sesuai dengan cara mereka masing-masing. Warga desa dapat terpengaruh oleh mereka karena mereka mempunyai status di dalam desa sehingga kepercayaan itu tumbuh di dalam diri warga desa. Selain itu saluran yang digunakan adalah saluran tradisional dimana penggerak-penggerak unjuk rasa dari warga setempat sehingga sudah mengetahui tradisi-tradisi yang ada di desa tersebut, maka pelaksanaan kekuasaan dapat berjalan dengan lancar.

Dalam konteks diskusi mengenai pengaruh kekuasaan memperlihatkan sebuah pentas pengaruh kekuasaan yang memiliki kekuatan pada strategi mewujudkan tujuan kekuasaan. Pada Pak IM dia cerdik di dalam pengemasan dalam menjalankan tujuannya untuk kepentingan pribadinya dan tujuan menguasai warga desa yang dijalankan melalui strategi pendekatan persuasif yang membuat tujuan ini terlindungi dari penolakan warganya. Strategi persuasif adalah strategi yang digunakan memang sudah menjadi kebutuhan warga desa. Seperti yang terjadi pada penelitian yang dilakukan Maring (2010) menggunakan analisis strategi persuasif dalam menjelaskan hubungan kekuasaan bernuansa persuasif melalui aparat kehutanan, pemerintah kolonial Belanda melakoni sebuah pentas kekuasaan dengan tujuan menguasai kawasan hutan. Langkah pemerintah kolonial untuk menentukan kawasan sesuai batas pewilayahan yang sudah ada dalam masyarakat merupakan strategi persuasif/normalisasi yang berhasil. Masyarakat tidak melihat penetapan pal batas sebagai sesuatu yang baru, tetapi bagian yang sudah ada. Begitu juga yang terjadi pada penelitian ini Pak IM melakukan unjuk rasa dengan tujuan memperjuangkan apa yang menjadi kebutuhan warganya sehingga warganya ikut di dalam aksi unjuk rasa, namun dibalik dari aksi tersebut adalah untuk melancarkan tujuan pribadinya. 
Tabel 13. Perbedaan strategi antar pihak yang menggerakkan aksi unjuk rasa

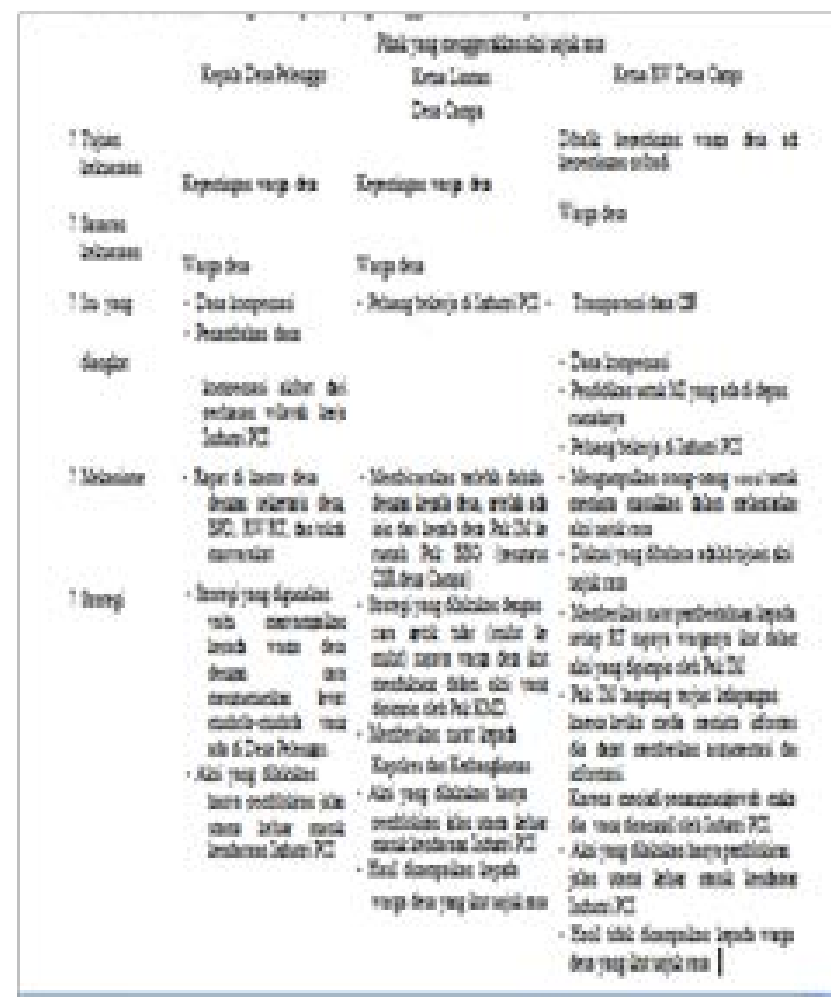

\section{KESIMPULAN}

1. Akar masalah timbulnya unjuk rasa terhadap Industri PCI adalah peluang bekerja, dana CSR dan ganti rugi perusahaan sebagai kompensasi kerusakan lingkungan yang terjadi. Jika dilihat berdasarkan jawaban responden yang paling banyak mengenai tuntutan yang pernah dilakukan yaitu peluang kerja di Industri PCI. Namun, jika dilihat berdasarkan hubungan kerja dengan Industri PCI, warga desa yang saat ini bekerja di Industri PCI tuntutan yang dilakukan yaitu peluang kerja dan dana CSR, sedangkan responden yang tidak bekerja di sana lebih menuntut peluang kerja dan dana ganti rugi.

2. Pada sikap dengan hadirnya Industri PCI terlihat bahwa semua responden memiliki sikap yang tidak jauh berbeda. Namun, jika dilihat berdasarkan perilaku unjuk rasa, responden yang tidak ikut unjuk rasa memiliki sikap lebih positif dibandingkan responden yang ikut unjuk rasa. Pada norma subjektif, responden melakukan unjuk rasa atas kemauannya sendiri dan juga perintah dari tokoh masyarakat. Hal ini menunjukkan bahwa warga desa melakukan aksi unjuk rasa atas kemauannya sendiri yang dapat diartikan adanya niat yang dimilikinya untuk melakukan unjuk rasa. Selain itu juga ada pengaruh kekuasaan pada perilaku responden. Pada kontrol perilaku yang dipersepsikan, responden yang ikut unjuk rasa mampu mengontrol dan menerima konsekuensi ketika melakukan unjuk rasa.

3. Pengaruh kekuasaan pemimpin lokal terhadap dinamika dan perilaku unjuk rasa warga desa cukup besar. Ada beberapa tujuan pemimpin lokal dalam mempengaruhi warganya diaataranya untuk mempertahankan apa yang menjadi hak warga desa dengan keberadaan Industri PCI.
Namun, ada pemimpin lokal yang memiliki tujuan ganda dalam mempengaruhi warganya yaitu selain untuk menjaga lingkungan dan kesempatan kerja bagi warga desa, dia juga memiliki kepentingan pribadi. Sebelum mereka melakukan unjuk rasa, mereka melakukan diskusi sesuai dengan cara masing- masing. Warga desa yang ikut unjuk rasa dapat terpengaruh karena mereka mempunyai status di desa sehingga kepercayaan tumbuh pada diri warga desa.

\section{DAFTAR PUSTAKA}

Ajzen, I. 1991. The Theory Planned Behavior. Organization Behavior and Human Decision Processess. 50: 179211

Anonim, Pedoman Tata Kerja No 017/PTK/II/2005(SK Kepala SKK Migas No. Kpts 08/BP00000/2005-S1) tentang Pedoman Pemberian Keterangan Keadaan Darurat, Pedoman Program Pengembangan Masyarakat dan Pedoman Kehumasan untuk Kontraktor Kontrak Kerja di Lingkungan Kegiatan Usaha Hulu Minyak dan Gas Bumi Anonim, Petrochina di demo pemuda Desa Campurejo. [Internet]. http://sisibjn.blogspot.com/2009/11/ petroch ina-di-demo-pemuda-desa.html diakses pada tanggal 28 Mei 2013.

Aryani, Alvita Tyas Dwi. 2010. Pengaruh Nilai Personal terhadap Sikap Akuntabilitas Sosial dan Lingkungan (Studi Kasus Mahasiswa Magister Akuntansi dan Magister Manajemen Undip). [Tesis]. Universitas Diponegoro: Semarang.

Astuti, Rini. 2013. REDD+ Sebagai Strategi-Strategi Kepengaturan dalam Tata Kelola Hutan di Indonesia: Sebuah Perspektif Foucauldian. WACANA Jurnal Transformasi Sosial ISSN 1410-1298 Nomor 30, Tahun XV, 2013 Halaman 71-97

Azwar, Saifuddin. 1998. Sikap Masyarakat Teori dan Pengukuran. Pustaka Pelajar: Yogyakarta.

Baron, Robert A dan Byrne, Donn. 2003. Psikologi Sosial Edisi Kesepuluh. Erlangga: Jakarta.

Dharmmesta, Basu Swastha. 1998. Theory of Planned Behavior dalam Penelitian Sikap, Niat dan Perilaku Konsumen. Jurnal KELOLA No. 18/VII/1998 ISSN: 0853-7046 Fakultas Psikologi UI. 2012. Psikologi Sosial. Sarwono, W dan Meinarno, Eko A, penyunting. Jakarta: Salemba Humanika

Foucault, Michel. 2002. P o w e r / K n o w l e d g e Wacana Kekuasaan/Pengetahuan. Bintang Budaya:Yogyakarta

Haryatmoko.2014. Etika Politik dan Kekuasaan. PT. Kompas Media Nusantara: Jakarta

Huda. Muhammad Nurul. 2011. Penetrasi Kapitalisme dan Transformasi Sosial di Bojonegoro: Studi Kasus Proyek Migas Blok Cepu. [Tesis]. Universitas Indonesia: Jakarta. Joner, John F. The Theory Of Attitude Fromation And Change And Its Application To Social Group Work. [Internet].http://web. psych.utoronto.ca/psy320/Required\%20readings files/week2-2.pdf diakses pada tanggal 21 Februari 
2013 Kementrian Sekretariat Negara Republik Indonesia. Peta Sumber Daya Alam.[Internent] http://www.indonesia.go.id/in/potensi-daerah/ sumber-daya-alam diakses pada tanggal 19 Mei 2012.

Maring, Prudensius. 2010. Bagimana kekuasan bekerja di balik konflik, perlawanan dan kolaborasi? Sebuah Sudut Pandang Antropologi Tentang Perebutan Sumberdaya Ekologi. Lembaga Pengkajian Antropologi Kekuasaan Indonesia: Jakarta Pusat

Muljono, Pudji. 2012. Metodologi Penelitian Sosial. IPB Press: Bogor

Prayogo, Dody. 2008. Corporate Social Responsibility, Social Justice dan Distributive Welfare dalamIndustriTambang dan Migas di Indonesia. Jurnal GALANG Vol.3 No 3, Desember 2008 Group: Jakarta

Ritzer, George, Goodman Douglas J. 2010. Teori Sosiologi Modern. Kencana Prenada Media

Sanusi, Bachrawi. 2004. Potensi ekonomi Migas Indonesia. Rineka Cipta: Jakarta

Setiadi , Elly M, Kolip, Usma. 2011. Pengantar Sosiologi Pemahaman Fakta dan Gejala Permasalahan Sosial: Teori, Aplikasi dan Pemecahannya.

Singarimbun, Masri, Effendi, Sofian. 2011. Metode Penelitian Survai. LP3ES. Jakarta

Sitorus, Felix. 1998. Penelitian Kualitatif "Suatu Perkenalan Kelompok Dokumentasi ilmu-ilmu Sosial untuk Laboratorium Sosiologi, Antropologi dan Kependudukan". Juruasan Ilmu Sosial dan Ekonomi Pertanian, Fakultas Pertanian IPB.

Soekanto, Soerjono .1982. Sosiologi Suatu Pengantar. Raja Grafindo Soekanto: Jakarta

Sumarjono, Maria.S.W, Nurhasan Ismail, Ernan Rustiadi, dan Abdullah Aman Damai. 2011. Pengaturan Sumber Daya Alam di Indonesia Antara yang Tersurat dan Tersirat Kajian Kritis Undang-undang Terkait Penataan Ruangan dan Sumberdaya Alam. Gajah Mada Univesity Press. Yogyakarta Suyanto, Bagong .2008. Industrialisasi Migas dan Ekspansi Masyarakat Lokal: Hasil Studi di Teluk Bintani, Papua. Masyarakat, Kebudayaan dan Politik, Tahun XXI, No 2, April - Juni 2008

Waysima. 2011. Pengaruh Ibu pada Perilaku Makan Ikan Laut Siswa Sekolah Dasar di Kabupaten Jepara dan Kabupaten Grobogan, Jawa Tengah. [Disertasi]. Sekolah Pascasarjana Institut Pertanian Bogor; Bogor 